PUBLISHER CORRECTION OPEN

(D) Check for updates

\title{
Publisher Correction: Linoleic acid-good or bad for the brain?
}

\author{
Ameer Y. Taha \\ npj Science of Food (2020)4:6 ; https://doi.org/10.1038/s41538-020-0066-4
}

Correction to: npj Science of Food https://doi.org/10.1038/s41538019-0061-9, published online 2 January 2020

In the original version of this Article, "atypical" in the Abstract was mistakenly changed to "a typical" at proof checking. This has now been corrected in the HTML and PDF versions of the Article.

\begin{abstract}
cc) (1)
Open Access This article is licensed under a Creative Commons International License, which permits use, sharing, adaptation, distribution and reproduction in any medium or format, as long as you give appropriate credit to the original author(s) and the source, provide a link to the Creative Commons license, and indicate if changes were made. The images or other third party material in this article are included in the article's Creative Commons license, unless indicated otherwise in a credit line to the material. If material is not included in the article's Creative Commons license and your intended use is not permitted by statutory regulation or exceeds the permitted use, you will need to obtain permission directly from the copyright holder. To view a copy of this license, visit http://creativecommons. org/licenses/by/4.0/.
\end{abstract}

(c) The Author(s) 2020 